\title{
FEASIBILITY STUDY ON WIND POWER GENERATION POTENTIAL IN PENINSULAR MALAYSIA
}

By

\section{SITI SOLEHAH BINTI MD RAMLI}

Thesis submitted in fulfillment of the requirements

for the degree of

Master of Science

June 2012 


\section{ACKNOWLEDGEMENT}

In the first place I would like to record my gratitude to my supervisor, Assoc. Prof. Dr. Ir Syafrudin Masri for his supervision, advice, and guidance from the very early stage of this research as well as giving me extraordinary experiences throughout the work. Besides, I gratefully acknowledge Dr. Norizah Mohamad as co-supervisor, for her help in guidance to fulfill my research.

Many thanks go in particular to Assoc. Prof Ahmad Syukri Yahya for his help in dealing with statistical analysis. His help and expertise on statistic helped me on analyzing process. I would also acknowledge Universiti Teknologi Mara (UiTM) and Ministry of Higher Education (MOHE) for the scholarship and research funding. The fund received through the Fundamental Research Grant Scheme (FRGS) entitle 'Feasibility Study on Wind Energy System' has allowed us to gain resources need for the completion of this study.

I would have not finished this research without the support from my husband Mohd Syawaludin Hussain, my parents Md Ramli Md Safian and Samsiah Din as well as the rest of my family who always been there for me whenever I need them, the encouragement they give to keep me going and their love to empower me that never fails all the time. Finally, I would like to thank everybody who was important to the successful realization of thesis, as well as expressing my apology that I could not mention personally one by one. 
ACKNOWLEDGEMENT ......................................... ii

TABLE OF CONTENTS .............................................. iii

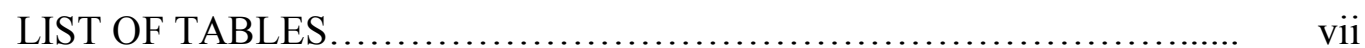

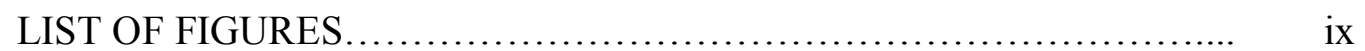

LIST OF ABBREVIATIONS ....................................... xi

LIST OF SYMBOLS ............................................. xii

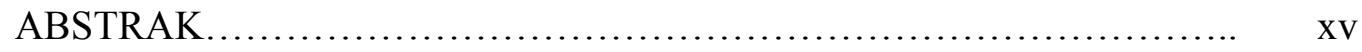

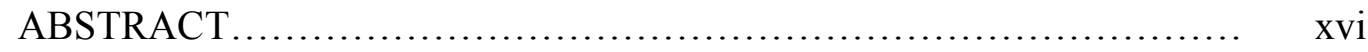

\section{CHAPTER 1 INTRODUCTION}

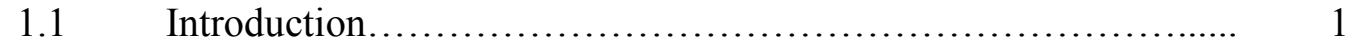

$1.2 \quad$ Motivation of Research........................................ 2

Problem Statement.............................................. 3

$1.4 \quad$ Objectives of the Research.................................... 4

1.5 Scope of Research...................................... 5

1.6 Contribution of the Research................................. 6

$1.7 \quad$ Thesis Outline................................................... 6

\section{CHAPTER 2 LITERATURE REVIEW}

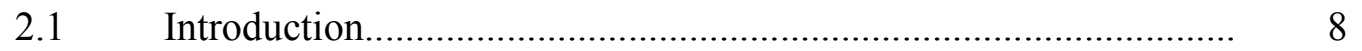


2.2 Wind Turbine and Power System.......................... 9

2.2.1 How Wind Turbine Work........................................................

2.2.2 Horizontal Axis Wind Turbine (HAWT)................. 10

2.2.3 Vertical Axis Wind Turbine (VAWT)..................... 11

2.2.4 Speed and Power Relations................................................... 12

2.2.5 Power Extracted from Wind.................................................... 13

2.2.6 Rotor Swept Area............................................................... 16

2.2.7 Air Denstiy.................................................................... 17

2.2.8 Wind Power System Classification......................................... 19

2.3 Statistical Analysis of Wind Speed Distribution.................. 19

2.3.1 Adjusment of Anemometers Height...................................... 20

2.3.2 Statistical Analysis of Weibull and Rayleigh Distribution.... $\quad 20$

2.3.3 Wind Power Density and Wind Energy Density .................... 25

2.3.4 Prediction Performance of Weibull and Rayleigh 26

Distribution.

2.3.5 Correlation Analysis and Multiple Regression 28

Analysis.

$2.4 \quad$ Techno-economic Analysis............................................................ 29

2.4.1 Wind Energy Output from Wind Turbine.............................. $\quad 30$

2.4.2 Capacity Factor.................................................................. $\quad 31$

2.4.3 Avaibility Factor................................................................ $\quad 32$

2.4.4 Economic Analysis.............................................................. 33

2.5 Review of Previuos Work...................................................... 35

2.5 Geography of Peninsular Malysia.................................................. 40 


\section{CHAPTER 3 METHODOLOGY}

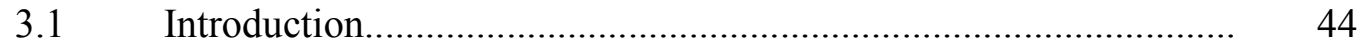

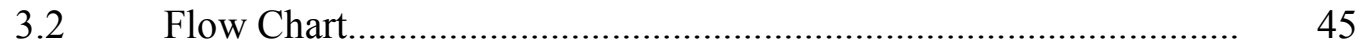

3.3 Studies on Wind Speed Characteristic in Peninsular Malaysia........ 47

3.4 Correlation Analysis and Multiple Regression Analysis........... 50

3.6 Experiment Procedure for Case Study.......................................... 52

\section{CHAPTER 4 RESULT AND DISCUSSION}

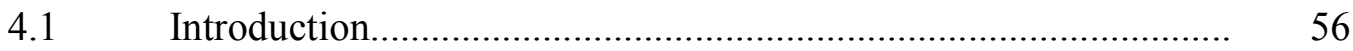

4.2 Wind Speed Distribution Analysis in Peninsular Malaysia........ 57

4.2.1 Annually Mean Wind Speed Distribution............................. 57

4.2.2 Monthly Mean Wind Speed Distribution............................... 60

4.3 Statistical Analysis........................................ 73

4.3.1 Weibull and Rayleigh Distribution........................................ $\quad 73$

4.3.2 Probability Density Function............................................... $\quad 75$

4.3.3 Cumulative Density Function................................................ $\quad 78$

4.3.4 Wind Power Density................................................................ $\quad 80$

4.3.5 Wind Energy Density............................................................ $\quad 81$

4.3.6 Prediction Performance of Weibull and Rayleigh 82

Distribution

4.4 Correlation Analysis and Multiple Regression Analysis................ 83

4.5 Wind Speed Distribution analysis at USM Engineering Campus... 86

4.5.1 Annually Mean Wind Speed.............................................. 86

4.5.2 Monthly Mean Wind Speed................................................. 88 
4.5.3 Hourly Mean Wind Speed.

4.5.4 Statistical Analysis of Wind Speed...................................... $\quad 90$

4.5.5 Techno-economic Analysis.................................................. 91

\section{CHAPTER 5 CONCLUSION AND RECOMMENDATION}

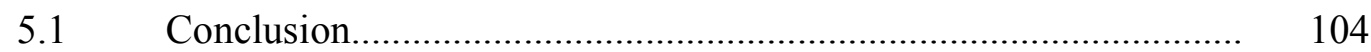

5.2 Achievement of the Research Objective......................... 105

5.2 Significance of the Research Work............................. 106

5.2 Suggestion for Future Development......................... 106

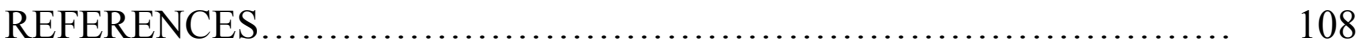

APPENDICES ..................................................... 113

Appendix A $\quad$ Weibull, Rayleigh Distribution, Annual Mean, Maximum 113 and Standard Deviation of Wind Speed.

Appendix B Comparison of Probability Density Function of Annual 114

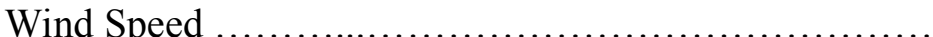

Appendix C Comparison of Cumulative Density Function of Annual Wind Speed

Appendix D Prediction Performance of Rayleigh and Weibull distribution

Appendix E Hourly Mean Wind Speed Variation at USM Engineering Campus.

Appendix F TR-2KW Wind Turbine Quatation.

Appendix G Rechargeable Battery Quatation.

Appendix H Rechargeable Battery Datasheet.

Appendix I List of Publication 


\section{LIST OF TABLES}

Page

Table 2.1 Commercially international system of classification for wind

Table 2.2 Types of correlation analysis

Table 2.3 The geography, climatic and topology of twelve selected locations in Peninsular Malaysia.

Table 3.1 Description of the selected locations in Peninsular Malaysia

Table 3.2 Technical data of the TR-2KW wind turbines

Table 4.1 Primary data of annually mean wind speed

Table 4.2 Annually mean wind speed at $10 \mathrm{~m}$ height

Table 4.3 Annually mean wind speed at 30m height

Table 4.4 Annually mean wind speed at 50m height

Table 4.5 Primary data of monthly mean wind speed

Table 4.6

Monthly mean wind speed at $10 \mathrm{~m}$ height

Table 4.7

Monthly mean wind speed at $30 \mathrm{~m}$ height

Table 4.8

Monthly mean wind speed at 50m height

Table 4.9

Weibull, Rayleigh distribution, annual mean, maximum and standard deviation of wind speed at $10 \mathrm{~m}$ height

Table 4.10

Annual mean wind power density at $10 \mathrm{~m}, 30 \mathrm{~m}$ and $50 \mathrm{~m}$ height

Table 4.11

Annual mean wind energy density at $10 \mathrm{~m}, 30 \mathrm{~m}$ and $50 \mathrm{~m}$ height

Table 4.12 Prediction performance of Rayleigh and Weibull distribution at $10 \mathrm{~m}$ height 
Table 4.13 Correlation of humidity, pressure, temperature and wind

Table 4.14 Analysis of Variance (ANOVA) 86

Table 4.15 Weibull, Rayleigh distribution, annual mean, maximum 91 and standard deviation of wind speed at USM

Engineering Campus

Table 4.16 Monthly energy output at USM Engineering Campus

Table 4.17 Capacity factor and availability factor

Table 4.18 Present value cost of TR-2KW wind turbine

Table 4.19 Specific cost, cost saving, payback time and net profit at USM Engineering Campus

Table $4.20 \quad$ Monthly energy output at $10 \mathrm{~m}$ height

Table 4.21 Monthly energy output at 30m height 98

Table 4.22 Monthly energy output at 50m height 99

Table 4.23 Capacity factor at 10m,30m and 50m height 100

Table 4.24 Availability factor at $10 \mathrm{~m}, 30 \mathrm{~m}$ and $50 \mathrm{~m}$ height 101

$\begin{array}{lll}\text { Table 4.25 } & \text { Specific cost at potential locations } & 101\end{array}$

Table 4.26 Cost saving, payback time and net profit at $10 \mathrm{~m}$ height 102

Table 4.27 Cost saving, payback time and net profit at 30m height 102

Table 4.28 Cost saving, payback time and net profit at 50m height 103 


\section{LIST OF FIGURES}

Page

$\begin{array}{lll}\text { Figure 2.1 Types of Horizontal Axis Wind Turbines, HAWT } & 10\end{array}$

Figure 2.2 Types of Vertical Axis Wind Turbines, VAWT 11

$\begin{array}{lll}\text { Figure } 2.3 \quad \text { Rotor efficiency versus } V_{0} / V \text { ratio } & 15\end{array}$

$\begin{array}{lll}\text { Figure 2.4 Rotor efficiency versus tip speed ratio for rotors with } & 16\end{array}$

$\begin{array}{lll}\text { Figure 2.5 } & \text { Map of Peninsular Malaysia } & 41\end{array}$

Figure 3.1 Flow chart for the overall work in the research 46

Figure 3.2 Location of Meteorological Department Station and School 48 of Electrical and Electronic Engineering

$\begin{array}{lll}\text { Figure } 3.3 & \text { Anemometers for wind speed measurement } & 48\end{array}$

$\begin{array}{lll}\text { Figure } 3.4 & \text { Wind vanes for wind direction measurement }\end{array}$

Figure 3.5 Data input dialog box of correlation analysis 51

Figure 3.6 Data input dialog box of multiple regression analysis 52

$\begin{array}{lll}\text { Figure } 3.7 & \text { TR-2KW wind turbine } & 53\end{array}$

Figure $3.8 \quad$ Power curve of $2 \mathrm{~kW}$ wind turbine generator 54

$\begin{array}{lll}\text { Figure 4.1 Monthly mean wind speed at 10m height } & 67\end{array}$

$\begin{array}{lll}\text { Figure } 4.2 & \text { Monthly mean wind speed at 30m height }\end{array}$

$\begin{array}{lll}\text { Figure 4.3 Monthly mean wind speed at 50m height } & 68\end{array}$

Figure 4.4 Comparison of probability density function of annual wind 77 speeds at (a) Langkawi and (b) Alor Star

Figure 4.5 Comparison of cumulative density function of annual wind 79 speeds at (a) Langkawi and (b) Alor Star 
Figure 4.6 Primary data of annual mean wind speed variation at USM

Figure 4.7 Secondary data of annual mean wind speed variation at USM Engineering Campus

Figure 4.8 Monthly mean wind speed variations at USM Engineering

Campus

Figure 4.9 Hourly mean wind speed variations at USM Engineering 90 Campus 


\section{LIST OF ABBREVIATIONS}

\begin{tabular}{|c|c|c|}
\hline AEO & - & Annual Energy Output \\
\hline ACS & - & Annual Cost Saving \\
\hline ANOVA & - & Analysis of Variance \\
\hline $\mathrm{COE}$ & - & Coefficient of Efficiency \\
\hline $\mathrm{CDF}$ & - & Cumulative Density Function \\
\hline DW & - & Durbin-Watson \\
\hline $\mathrm{E}$ & - & East \\
\hline MAE & - & Mean Absolute Error \\
\hline $\mathrm{N}$ & - & North \\
\hline NP & - & Net Profit \\
\hline PDF & - & Probability Density Function \\
\hline PT & - & Payback Time \\
\hline PVC & - & Present Value Cost \\
\hline $\mathrm{R}$ & - & Rayleigh \\
\hline RMSE & - & Root Mean Square Error \\
\hline S & - & South \\
\hline $\mathrm{SC}$ & - & Specific Cost \\
\hline TNB & - & Tenaga Nasional Berhad \\
\hline VAWT & - & Vertical Axis Wind Turbine \\
\hline W & - & West \\
\hline WPD & - & Wind Power Density \\
\hline WED & - & Wind Energy Density \\
\hline
\end{tabular}




\section{LIST OF SYMBOLS}

\begin{tabular}{|c|c|c|}
\hline$\alpha$ & - & Power law exponent \\
\hline$A$ & - & Swept area of rotor \\
\hline$A_{F}$ & - & Availability factor \\
\hline$C$ & - & Scale parameter \\
\hline$C_{o m r}$ & - & Cost of operation maintenance and repair \\
\hline$C_{w t}$ & - & Cost of wind turbine \\
\hline$C_{c w}$ & - & Cost of installation and civil work \\
\hline$C_{P}$ & - & Power coefficient of the rotor \\
\hline$C_{F}$ & - & Capacity factor \\
\hline$D$ & - & Diameter of rotor blade \\
\hline$D_{c}$ & - & Maximum rotor at the center \\
\hline$D_{f}$ & - & Degree of freedom \\
\hline$E_{T A}$ & - & Actual wind energy output, \\
\hline$E_{T R}$ & - & Rated wind energy \\
\hline$f(V)$ & - & Probability density function \\
\hline$F(V)$ & - & Cumulative distribution function \\
\hline$H$ & - & Height of the rotor \\
\hline$H_{1}$ & - & Height of $10 \mathrm{~m}$ above the ground level \\
\hline $\mathrm{H}_{2}$ & - & Height above the ground level \\
\hline$H_{m}$ & - & Site elevation \\
\hline$i$ & - & Interest rate \\
\hline
\end{tabular}




\begin{tabular}{|c|c|c|}
\hline$I$ & - & Investment \\
\hline$k$ & - & Shape parameter \\
\hline$m$ & - & Kinetic energy in the air mass \\
\hline$m_{f}$ & - & Mass flow rate \\
\hline$n$ & - & Number of nonzero wind speed data points \\
\hline$N$ & - & Number of observations. \\
\hline$\rho$ & - & Air density \\
\hline$\rho_{0}$ & - & Sea level standard atmospheric pressure \\
\hline$\Gamma$ & - & Gamma function \\
\hline$\sigma$ & - & Standard deviation \\
\hline$P$ & - & Mechanical power in the moving air \\
\hline$P_{O}$ & - & Mechanical power extracted by the rotor \\
\hline$P(V)$ & - & Power of the wind \\
\hline$P_{R}$ & - & Rated power \\
\hline$P_{T}(V)$ & - & Wind power output from the wind turbine \\
\hline$P_{R}$ & - & Rated power \\
\hline$p$ & - & Air pressure \\
\hline$r$ & - & Inflation rate \\
\hline$R$ & - & Specific gas constant for dry air \\
\hline$R^{2}$ & - & Correlation coefficient \\
\hline$S$ & - & Scrap values \\
\hline$T$ & - & Temperature on the absolute scale \\
\hline$t$ & - & Lifetime of wind turbine \\
\hline
\end{tabular}

xiii 


$\begin{array}{lll}v_{m} & - & \text { Mean value of the wind speed } \\ V_{1} & - & \text { Wind speed at height } H_{1} \\ V_{2} & - & \text { Wind speed at height } H_{2} \\ V_{i} & - & \text { Observed mean monthly wind speed } \\ V & - & \text { Upstream wind velocity at the entrance of the rotor blade } \\ V_{0} & - & \text { Downstream wind velocity at the exit of the rotor blade } \\ V_{I} & - & \text { Cut-in wind speed } \\ V_{R} & - & \text { Rated wind speed } \\ V_{0} & - & \text { Cut-off wind speed } \\ V_{M P} & - & \text { Most frequent wind speed } \\ V_{M A X E} & - & \text { Wind speed carrying maximum energy } \\ x_{i} & - & i^{t h} \text { predicted data with the Weibull and Rayleigh distribution } \\ y_{i} & - & i^{t h} \text { Actual data } \\ z & - & \text { Mean of the actual data }\end{array}$




\title{
KAJIAN KEBOLEHLAKSANAAN POTENSI PENJANAAN KUASA ANGIN DI SEMENANJUNG MALAYSIA
}

\begin{abstract}
ABSTRAK
Data kelajuan angin di antara tahun 2005 hingga 2009 telah dianalisis di sebelas lokasi terpilih di Semenanjung Malaysia dan data di Kampus Kejuruteraan, USM telah digunakan sebagai kajian kes. Data analisis menunjukkan bahawa kawasan berpotensi untuk pemasangan turbin angin adalah di Kota Bharu di mana purata tahunan kelajuan angin adalah didapati sekitar $3.46 \mathrm{~m} / \mathrm{s}$ pada ketinggian $50 \mathrm{~m}$. Analisis korelasi dan regresi berganda juga telah dijalankan dan keputusan menunjukkan bahawa parameter tekanan, suhu dan kelembapan tidak mempengaruhi ciri kelajuan angin di Semenanjung Malaysia. Analisis tekno-ekonomi telah dijalankan menggunakan turbin angin paksi mendatar, TR-2kW dan keputusan kajian menunjukkan bahawa keuntungan maksimum diperolehi di Kota Bharu. Keluaran tenaga tahunan yang tertinggi, AEO dikira menjadi 2,584.02 $\mathrm{kWj}$ pada ketinggian $50 \mathrm{~m}$. Kajian menunjukkan bahawa pemasangan turbin angin di Kota Bharu akan mendapat keuntungan bersih sebanyak RM 1,616.30 dengan tempoh bayar balik 17.13 tahun. Untuk mengurangkan kerugian, turbin angin paksi tegak seperti turbin angin Savonius disyorkan untuk dipasang di lokasi di lokasi yang lebih baik di Malaysia
\end{abstract}




\title{
FEASIBILITY STUDY ON WIND POWER GENERATION POTENTIAL IN PENINSULAR MALAYSIA
}

\begin{abstract}
The wind speed data of year 2005 to 2009 has been analysed at eleven selected locations in Peninsular Malaysia and the data at USM Engineering Campus had been used as a case study. The analytical data shows that the best potential area for wind turbine installation is at Kota Bharu where the annual mean wind speed is found to be around $3.46 \mathrm{~m} / \mathrm{s}$ at $50 \mathrm{~m}$ height. The correlation and multiple regression analysis also have been conducted and the results reveal that the pressure, temperature and humidity parameter does not influence the wind speed characteristic in Peninsular Malaysia. The techno-economic analysis has been performed using horizontal axis wind turbine, TR$2 \mathrm{~kW}$ and the result indicates that the maximum profit is achieved at Kota Bharu. The maximum annual energy output, AEO is calculated to be $2,584.02 \mathrm{kWh}$ at $50 \mathrm{~m}$ height. The study shows that the installation of wind turbine at Kota Bharu will accumulated a net profit of RM 1,616.30 with a payback period of 17.13 years. To reduce the loss, the vertical axis with low cut in speed such as Savonius wind turbine is recommended to be installed at a better location in Malaysia
\end{abstract}




\section{CHAPTER 1 \\ INTRODUCTION}

\section{$1.1 \quad$ Introduction}

Recently, the development of wind energy as one of the renewable energy has growing rapidly in many countries worldwide. By the end of 2001, it is recorded that the total operational wind power capacity worldwide was around 23,270MW which distributed to the five continents. The highest percentage of installed capacity was about $70.3 \%$ in Europe followed by $19.1 \%$ in North America. Asia and Pacific acquiring $9.3 \%$ of the total installed capacity respectively. The lower percentage was about $0.9 \%$ and $0.4 \%$ in the Middle East and Africa and in the South and Central America significantly (Ackermann and Söder, 2000).

Various assessment of wind potential has been performed by many countries such as Germany, Holland, Greece, India, China, Turkey, Taiwan, Thailand and others. Hence, Malaysia is included in exploiting the wind energy potential as a renewable energy which brings numerous benefits to our country. Malaysia is luxuriously endowed with fossil energy resources such as natural gas, coal, and crude oil. Besides, the country also richly endowed with renewable energy resources such as solar, wind, biomass, biogas, and others.

Malaysia sits on the South China Sea in the center of Southeast Asia. The country divided into two regions namely as Peninsular Malaysia (West Malaysia) and Sabah and Sarawak (East Malaysia). The total area of Malaysia is approximately $330,000 \mathrm{~km}^{2}$ at which Peninsular Malaysia comprises of $40 \%$ of the total area. The location of Malaysia is located near the equator. Hence, the climate of Malaysia is 
categorized as equatorial. Besides, the climates of regions in Malaysia are moderately hot and extremely sultry except at highland. Throughout the year, the average temperature in Malaysia is varies from $20^{\circ} \mathrm{C}$ to $30^{\circ} \mathrm{C}$ meanwhile the average precipitation in Peninsular Malaysia is about 2500mm. East Malaysia, however receiving higher rainfall than Peninsular Malaysia which is approximately $5080 \mathrm{~mm}$ significantly. In addition, Malaysia faces two monsoon wind seasoned known as Northeast monsoon and Southwest monsoon. During the Northeast monsoon, the rainfall is heavy than Southwest monsoon at which the average precipitation is around $2500 \mathrm{~mm}$ respectively (AsianInfo, 2011).

\subsection{Motivation of Research}

For many decades, the fossil fuel such as crude oil, natural gas and coal is the sources for energy generation. However, these sources will soon start to diminish while the demand has continuously increased resulting in incessantly energy crisis. Hence, many countries have starting to look at the alternative renewable energy sources to overcome this declines and the awareness of using clean energy has been created by the global environmental concerns. Besides the declined of energy generation, the use of fossil fuels acquire many negative effects such as air pollution, acid rain and global warming. Burning any fossil will produce the carbon dioxide which contributed to the greenhouse effect and global warming. It is also produced sulphur dioxide, a gas that contributed to acid rain. By converting to the clean energy sources would enable the world to improve the quality of life. The contaminated environment also can be minimized (Sopian et al., 2005). 
The wind energy has many advantages. One of the advantages is it is free and with modern technology, it can be captured efficiently. Once the wind energy is built, the energy produces does not cause green houses and pollution. The remote area which is not connected to the electricity power grid is able to utilize wind turbine to generate electricity. Besides, the reliance on electricity supply company can be reduced and gain high income if the wind energy project is successful. With the advantages of wind energy system, many countries including our country have looked at this renewable energy to overcome the fossil fuels sources crisis and also the cost of energy.

\subsection{Problem Statement}

The potential of wind power generation is depends on the availability of the wind resource that varies with location. It is important to understand the site-specific nature of the wind before wind energy project can be performed (Sopian et al., 2005). A lot of studies have been conducted to assess the wind energy potential in Malaysia. (Exell and Fook, 1986) have conducted the wind energy potential in Malaysia. The five year wind speed data (1976 to 1980) at five locations has been analyzed in their study. There is only three areas in Peninsular Malaysia has been selected to performed this evaluation. Moreover, (Sopian et al., 1995) also have carried out the assessment of wind energy potential in Malaysia following the same method. In their studies, the number of selected location to determine the potentially of wind power generation has been increased as much as ten location and the wind speed data were obtained from the four different types of station such as station near open sea, station located at airport, flat area and at meteorological department. The wind speed data has been collected from 1982 to 1991. Nevertheless, there are only six regions in Peninsular Malaysia has been selected 
in their studies. However, the economic analysis had not been carried out to determine the profitability of installing wind turbine at the selected location.

Many locations in Peninsular Malaysia haven't explored yet. Thus, these challenges are the motivation to continually study about the wind power generation potential in Peninsular Malaysia specifically. The approach which will be taken in this study is to obtain the wind speed data from Meteorological Department Station at eleven selected locations in Peninsular Malaysia. Besides, the data also is obtained from the School of Electrical and Electronic, USM Engineering Campus as a case study. The recent data of year 2005 until 2009 will be employed in this analysis. Then, the data will be analyzed to identify which location has potential of wind power. To complete this feasibility study, the techno-economic analysis will be performed. The result of technoeconomic analysis is employed to conclude the potentiality and profitability of wind power generation in Peninsular Malaysia.

\subsection{Objectives of the Research}

According to the problem statement that has been explained in previous section, then it is identified three main objectives of the research which are:

a) To perform an assessment of wind power generation potential at selected location in Malaysia's peninsular area.

b) To determine the parameters affected wind speed characteristic.

c) To accomplish the techno-economic analysis at selected location in Peninsular Malaysia. 


\subsection{Scope of the Research}

The scope of the research covers the feasibility study on wind power potential in Peninsular Malaysia. Firstly, the data of wind speed distribution will be obtained from Meteorological Department Station Malaysia. There are twelve locations in Peninsular Malaysia will be selected which is Langkawi, Alor Star, Penang, Sitiawan, Ipoh, Kuala Lumpur, Kuantan, Kuala Terengganu, Kota Bharu, Mersing and Johore Bharu and USM Engineering Campus as a case study. The wind speed data variation of year 2005 until year 2009 which was recorded every minute will be used to carry out the analysis.

Secondly, the wind speed data distribution will be analyzed. The data will be divided into two categories which are annually and monthly wind speed. The data will be standardized to the three level of height which is $10 \mathrm{~m}, 30 \mathrm{~m}$ and $50 \mathrm{~m}$. The results will be illustrated in tables and graphs. For the case study, the wind speed data will be analysed in three categories which are annually, monthly and hourly.

Thirdly, the statistical analysis will be performed using two distribution model known as Weibull and Raleigh distribution model. The probability density function, PDF and cumulative density function, CDF also will be determined in this analysis. After that, the wind power density WPD, and wind energy density, WED will be performed. Subsequently, the prediction performance of Weibull and Rayleigh distribution model will be carried out. The Microsoft Excel and Easy-Fit software will be employed in this statistical analysis.

Next, the correlation analysis and multiple regression analysis will be performed to determine the strength and serial correlation between wind speed and other parameters that affected the wind speed characteristic. The independent variable and dependent variable will be distinguished. In this analysis, the STATGRAPHICS 
Centurion software will be employed. Afterward, the wind turbine characteristic will be executed. Finally, the techno-economic analysis will be performed to determine the payback time and the net profit of installing wind power system at potential locations.

\subsection{Contribution of the Research}

From this research, the assessment of wind power potential at eleven selected locations in Peninsular Malaysia is performed. Besides, this assessment also is conducted at USM Engineering Camps as a case study. Based on the results, the potential location is identified and the economic analysis is performed. Then, the parameter affected the wind speed characteristics is determined. Finally, the type of wind turbine which is suitable to the wind speed characteristic in Peninsular Malaysia is determined.

\subsection{Thesis Outline}

This thesis is divided into five chapters. The first chapter provides and introduction of this research. The problem statement as well as the motivation also will be discussed. The objectives, scope and contribution of the research are also covered in this chapter. This chapter clarifies the idea of the overall research by providing the basic understanding of the research.

The second chapter focuses on the literature review. It is presents the reader with the applicable theory about wind turbine and power system, review of previous work, geography of Peninsular Malaysia and techno-economic analysis. 
The third chapter discusses the outline of statistical analysis of wind speed distribution. Besides, the procedure in performing multiple regression analysis, wind turbine characteristic estimation and economic analysis is included in this chapter. The Microsoft Excel, Easy-Fit and STATGRAPHICS Centurion software's is employed in this analysis.

The fourth chapter covers the results of study. It is started from the results of annually then monthly wind speed distribution analysis at eleven selected locations. After that, the results of Weibull and Rayleigh distribution analysis are discussed in the next section. The prediction performance of Weibull and Rayleigh distribution is also discussed. Then, the results of probability density function, PDF, cumulative density function, CDF, wind power density, WPD, wind energy density, WED. For the case study, the detail analysis of wind speed distribution is conducted by performing the annually, monthly, and hourly wind speed. Besides, the result of correlation analysis and multiple regression analysis is discussed. Then, the wind turbine characteristic and economic analysis is carried out and discussed at USM Engineering Campus and at potential locations in Peninsular Malaysia.

Chapter five is the final chapter in this thesis. This chapter concludes the whole research. It also states achievement of research objectives, significance of research work and suggestion for future work. 


\section{CHAPTER 2}

\section{LITERATURE REVIEW}

\subsection{Introduction}

The wind energy capacity has been applied in many centuries to sail ships, grind grains and pump water in rural areas. Currently, the limitation of fossil fuel sources, increment cost of fuel sources and the negative environmental impact make the renewable energy become a great importance. Wind sources as a renewable energy are clean, free and unlimited. This type of sources has great advance in offering benefits to our environment and economic compare to the conventional energy sources. Hence, the role of renewable energy resources such as wind has growing rapidly as the generating cost decrease. To design and apply the wind power system, the detail knowledge and assessment of wind characteristic at the specific site should be carried out. Thus, in this research, the feasibility study on wind power generation potential in Peninsular Malaysia will be performed.

This chapter covers the literature review on an assessment of wind power generation potential in Peninsular Malaysia. The wind turbine and power system is discussed in Section 2.2. This section comprises of eight subsections which is how wind turbine work, horizontal axis wind turbine HAWT, vertical axis wind turbine VAWT, speed and power relations, power extracted from wind, rotor swept area, air density, and wind power classification. Meanwhile, Section 2.3 covers the review of statistical analysis of wind speed distribution. It is consist of five subsections which is adjustment of anemometers height, statistical analysis of Weibull and Rayleigh distribution, wind power density and wind energy density, prediction performance of Weibull and 
Rayleigh distribution, and correlation analysis and multiple regression analysis. Next, Section 2.4 focuses on techno-economic analysis. In this section, the wind energy output from a wind turbine, capacity factor availability factor and economic analysis has been discussed. Then, Section 2.5 covers the review of previous work. Finally, the literature review of geography of Peninsular Malaysia is covers in Section 2.6.

\subsection{Wind Turbine and Power System}

The wind turbines are useful in generating the electricity. The large wind turbines enable to produce high power and contribute electricity to the power grid for the commercial purposes. Wind turbines also supply the electricity at the remote area especially at the small villages which far away from the transmission lines of the commercial area. Besides producing the electricity for the wind farm, water pumping and ice making purposes, it also help to remove the salt from the ocean water (Schlager and Weisblatt, 2006).

\subsubsection{How Wind Turbine Work}

The technology of wind turbine is simple. The wind turbine captures the wind's kinetic energy in a rotor consisting of two or more blades mechanically couple to an electrical generator. The turbine is mounted on a tall tower to enhance the energy capture. The higher the tower, the energy capture will be higher. Many wind turbines are installed at one site to build a wind far of the desired power production capacity. The sites with steady high wind produce more energy over the year (Patel, 2006). The wind turbines are manufactured in two type's namely as vertical and horizontal axis wind turbine. 


\subsubsection{Horizontal Axis Wind Turbine (HAWT)}

The horizontal axis wind turbines (HAWT) comprises of single, double, three or multiblade wind turbine. However, most of turbines built today are two and three blade. The rotor of wind turbine will convert the linear motion of the wind into rotational energy and then it will drive the generator. The horizontal axis turbine is divided into upwind and downwind turbine. The higher power of wind turbine can be obtained using the upwind turbine. It has lower noise, lower blade fatigue and smoother output power. Nevertheless, the downwind wind turbines allow the use of free yaw system. Besides, it allows the blades to deflect away from the tower when loaded (Patel, 2006). Figure 2.1 present the types of blades of horizontal axis wind turbine (HAWT). In this research, the horizontal axis wind turbine with the three blades is installed at USM Engineering Campus as a case study. Using the wind turbine, the wind turbine characteristic is computed. The results is used to determine the potentiality and profitably of installing wind turbine at this case study and at potential locations.

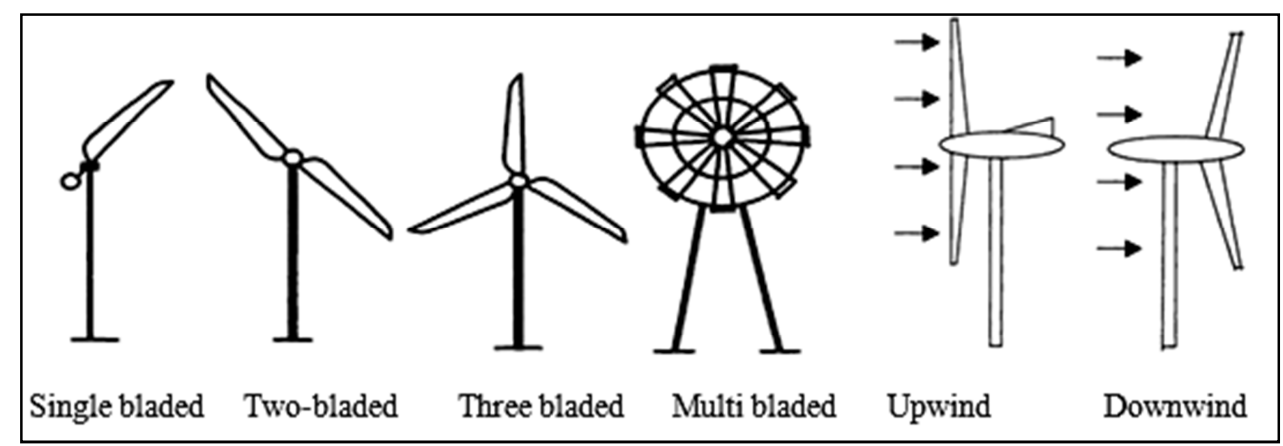

Figure 2.1: Types of Horizontal Axis Wind Turbines, HAWT 


\subsubsection{Vertical Axis Wind Turbine (VAWT)}

Generally, there are four types of Vertical Axis Wind Turbine (VAWT) known as curved-blade (or "Egg-beater" type) Darrieus, straight-bladed Darrieus, Savoniustype and H-Rotor-type. It has several advantages such as the structure of VAWT is simple. The vertical drive shaft simplifies the installation of the gear box and electrical generator on the ground. It also unidirectional and requires no yaw mechanism to continuously orient itself towards the wind direction. However it also has drawback at which it required the guy wires attached to the top of wind turbine for the supporting purposes. The utilization of VAWT today is not widely used. This is because the output power is difficult to control especially in the high wind simply by changing the blade pitch. Darrieus configuration may be utilized for large power capacity application with modern technologies such as low cost and variable speed power electronic emerging in the wind power industries (Patel, 2006). The types of VAWT is illustrated in Figure 2.2.

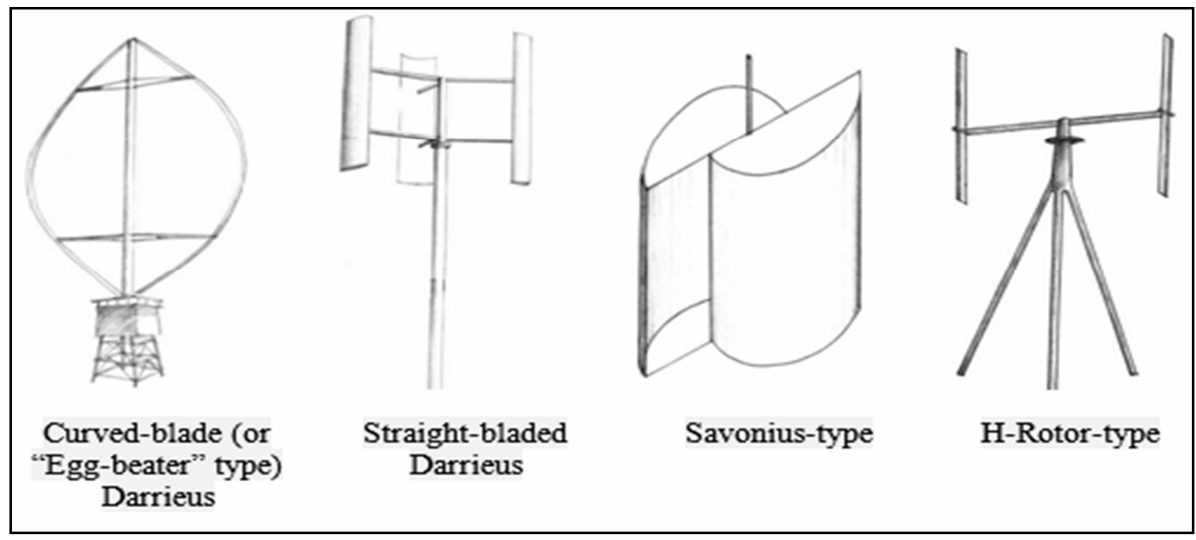

Figure 2.2: Types of Vertical Axis Wind Turbines, VAWT 


\subsubsection{Speed and Power Relations}

The kinetic energy in air mass, $m$ moving with speed, $V$ is given by the following in SI units (Patel, 2006):

$$
\text { Kinetic Energy }=\frac{1}{2} \cdot m \cdot V^{2} \text { joules }
$$

The power in moving air is the flow rate of kinetic energy per second (Patel, 2006).

$$
\text { Power }=\frac{1}{2} \cdot(\text { mass flow per second }) . V^{2}
$$

If we let:

$P=$ mechanical power in the moving air

$\rho=$ air density, $\mathrm{kg} / \mathrm{m}^{3}$

$A=$ area swept by the rotor blades, $\mathrm{m}^{2}$

$V=$ velocity of the air, $\mathrm{m} / \mathrm{s}$

Then, the volumetric flow rate is $\mathrm{A} \cdot \mathrm{V}$, the mass flow rate of the air in kilograms per second is $\rho \cdot \mathrm{A} \cdot \mathrm{V}$ and the power is given by the following (Patel, 2006):

$$
P=\frac{1}{2}(\rho A V) \cdot V^{2}=\frac{1}{2} \rho A V^{3}
$$




\subsubsection{Power Extracted From Wind}

The actual power extracted by the rotor blades is the difference between the upstream and downstream wind power (Patel, 2006). That is, using Equation 2.2:

$$
P_{O}=\frac{1}{2} \text { mass flow rate per second. }\left\{V^{2}-V_{0}^{2}\right\}
$$

Where:

$P_{O}=$ mechanical power extracted by the rotor

$V=$ upstream wind velocity at the entrance of the rotor blades

$V_{0}=$ downstream wind velocity at the exit of the rotor blades.

The air velocity is discontinuous from $V$ to $V_{0}$ at the "plane" of the rotor blades in macroscopic sense. The mass flow rate of air through the rotating blades is, therefore derive by multiplying the density with the average velocity. The mass flow rate is given as (Patel, 2006):

$$
m_{f}=\rho \cdot A \cdot \frac{V+V_{0}}{2}
$$

The mechanical power extracted by the rotor which is driving the electrical generators is therefore (Patel, 2006):

$$
P_{O}=\frac{1}{2}\left[\rho \cdot A \cdot \frac{V+V_{0}}{2}\right] \cdot\left(V^{2}-V_{0}^{2}\right)
$$


The above expression can be algebraically rearranged(Patel, 2006):

$$
P_{O}=\frac{1}{2} \rho \cdot A \cdot V^{3} \frac{\left(1+\frac{V_{O}}{V}\right)\left[1-\left(\frac{V_{O}}{V}\right)^{2}\right]}{2}
$$

The power extracted by the blades is expressed as a fraction of the upstream wind power as follows(Patel, 2006):

$$
P_{O}=\frac{1}{2} \rho \cdot A \cdot V^{3} \cdot C_{P}
$$

Where $C_{P}$ is the fraction of the upstream wind power, which capture by the rotor blades. The remaining power is discharged or wasted in the downstream wind. The factor $C_{P}$ is called power coefficient of the rotor or rotor efficiency. The $C_{P}$ value is depends on the ratio of the downstream to the upstream wind speed that is $\left(V_{0} / V\right)$ (Patel, 2006):

$$
C_{p}=\frac{\left(1+\frac{V_{0}}{V}\right)\left[1-\left(\frac{V_{0}}{V}\right)^{2}\right]}{2}
$$

The plot of power coefficient versus $\left(V_{0} / V\right)$ shows that $C_{P}$ is a single, maximum-value function which is shown in Figure 2.3. It has maximum value of 0.59 when the $\left(V_{0} / V\right)$ is one-third. The maximum power is extracted from the wind at that 
speed ratio, when the downstream wind speed equals one-third of the upstream speed. Under this condition (Patel, 2006):

$$
P_{\max }=\frac{1}{2} \rho \cdot A \cdot V^{3} \cdot 0.59
$$

Theoretically, the maximum value of $C_{P}$ is about 0.59 respectively. Generally, the maximum values of $C_{P}$ can be achieved as much as 0.5 for high speed two blade turbine while for the slow speed, it is ranged from 0.2 to 0.4 with more blade as shown in Figure 2.4.

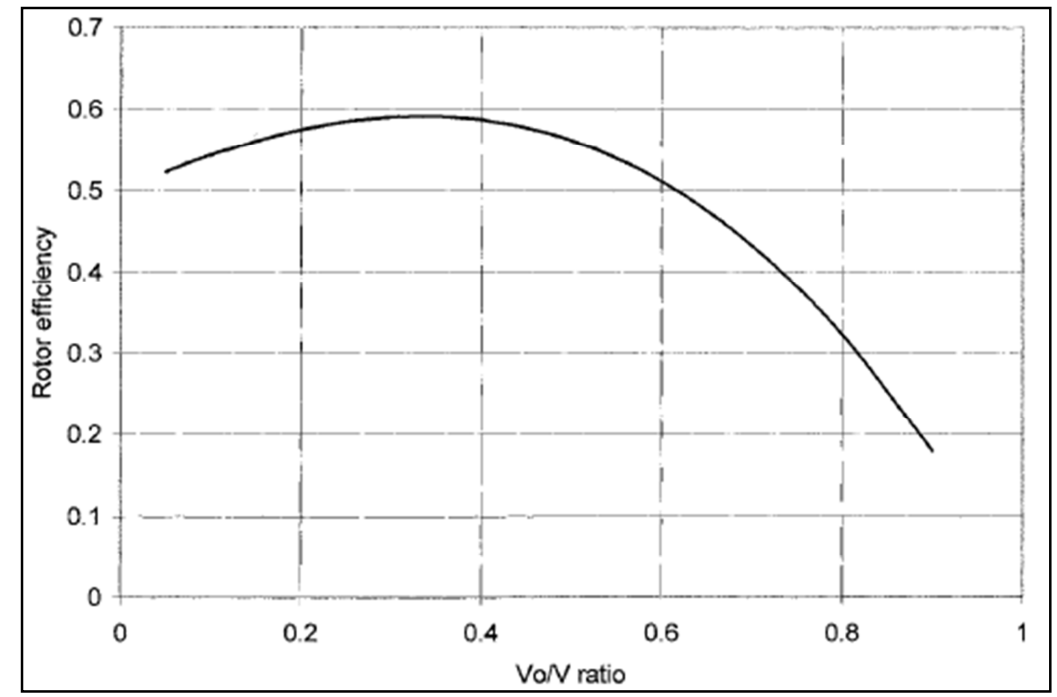

Figure 2.3: Rotor efficiency versus $V_{0} / V$ ratio 


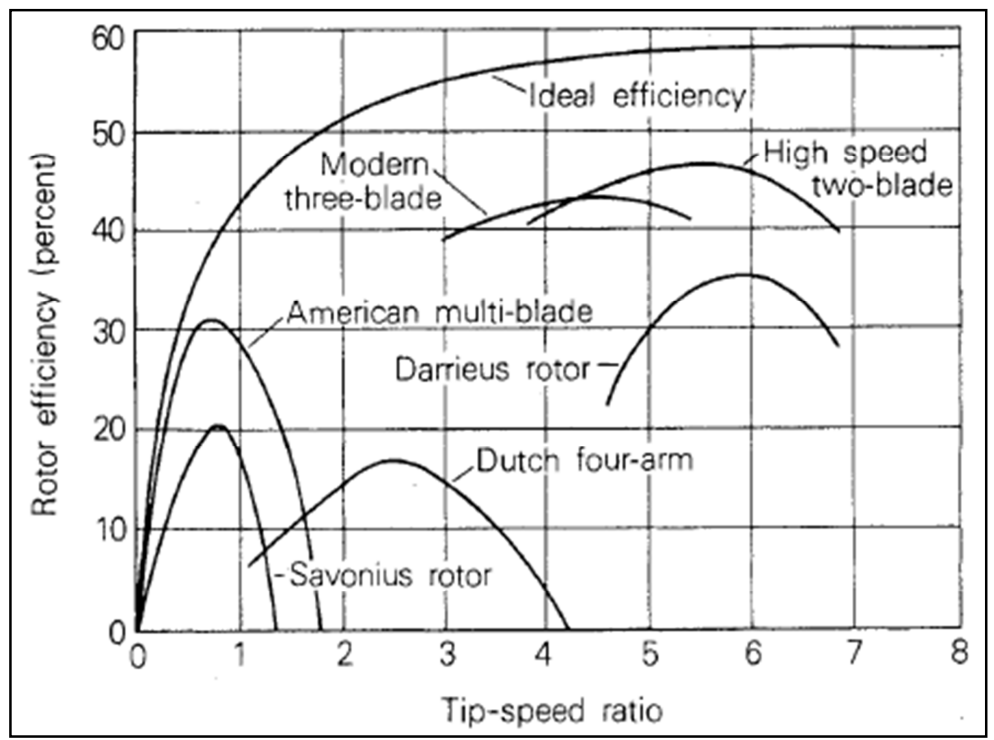

Figure 2.4: Rotor efficiency versus tip speed ratio for rotors with different numbers of blades

\subsubsection{Rotor Swept Area}

Referring to the Equation 2.4, it is notices that the output of wind turbine varies linearly with the rotor swept area. Hence, for the HAWT, the rotor swept area is given as (Patel, 2006):

$$
A=\frac{\pi}{4} D^{2}
$$

Where $D$ is rotor diameter of blade. The swept area of VAWT such as Darrieus, determination of the swept area is complex, as it involves elliptical integrals. However, approximating the blade shape as a parabola leads to the following simple expression for the swept area (Patel, 2006): 


$$
A=\frac{2}{3} D_{c} H
$$

Where:

$D_{c}=$ Maximum rotor at the centre

$H=$ Height of the rotor

The wind turbine efficiently intercept the wind energy flowing through the entire swept area even though it has only two or three thin blade with the solidity between 5 to 10 percent. Solidity is defined as the ratio of the solid area to the swept area of the blades.

\subsubsection{Air Density}

Beside swept area of wind turbine, the wind power also varies linearity with the air density. Air density $\rho$ varies with the pressure and temperature in accordance with the gas law. It is given by (Patel, 2006):

$$
\rho=\frac{p}{R . T}
$$

Where:

$p=$ Air pressure

$T=$ Temperature on the absolute scale

$R=$ Specific gas constant for dry air is about $287.058 \mathrm{~J} /(\mathrm{kg} . \mathrm{K})$ 
The air density at sea level, on atmospheric pressure $(14.7 \mathrm{psi})$ and $60^{\circ} \mathrm{F}$ is about $1.225 \mathrm{~kg} / \mathrm{m}^{3}$. The air density is corrected for site specific temperature and pressure. Both parameters varied with the altitude. Their combined effect on the air density is given by (Patel, 2006):

$$
\rho=\rho_{0} \cdot e^{-\left\{\frac{0.297 H_{m}}{3048}\right\}}
$$

Where:

$\rho_{0}=$ Sea level standard atmospheric pressure is about $101.325 \mathrm{kPa}$.

$H_{m}=$ Site elevation

Equation 2.9 is valid up to $6000 \mathrm{~m}$ of the site elevation above the sea level. It can be simply written as (Patel, 2006):

$$
\rho=\rho_{0}-1.194 \cdot 10^{-4} \cdot H_{m}
$$

The air density correction at high elevations can be significant. For example, the air density at 2,000 m elevation would be $0.986 \mathrm{~kg} / \mathrm{m}^{3}, 20 \%$ lower than the $1.225 \mathrm{~kg} / \mathrm{m}^{3}$ value at sea level. For ready reference, the temperature varies with the elevation (Patel, 2006):

$$
T=15.5-\frac{19.83 H_{m}}{3048}{ }^{\circ} \mathrm{C}
$$




\subsubsection{Wind Power System Classification}

Wind power system is classified into seven classes accordingly to the international wind system classification. The class of wind power is increases as well as the mean wind speed and elevation is increases. Consequently, the wind power density also is increases. For instance, the mean wind speed at $10 \mathrm{~m}$ height which is less than or equal to $4.4 \mathrm{~m} / \mathrm{s}$ is categorized in class 1 wind category. Meanwhile, at $30 \mathrm{~m}$ and $50 \mathrm{~m}$ height, the mean wind speed is less than or equal to $5.1 \mathrm{~m} / \mathrm{s}$ and $5.6 \mathrm{~m} / \mathrm{s}$ respectively. It is also included in the same class of class 1 wind category. The wind power density is also increases at three level of height. It is increases from $\leq 100 \mathrm{~W} / \mathrm{m}^{2}$ at $10 \mathrm{~m}$ to $\leq 200 \mathrm{~W} / \mathrm{m}^{2}$ at $50 \mathrm{~m}$. Table 2.1 shows the detail description of wind energy system classification from class 1 to class 7 wind categories.

Table 2.1: Commercially international system of classification for wind

\begin{tabular}{|c|c|c|c|c|c|c|}
\hline $\begin{array}{c}\text { Wind } \\
\text { power class }\end{array}$ & $\begin{array}{c}10 \mathrm{~m} \text { Wind } \\
\text { power density } \\
\left(\mathrm{W} / \mathrm{m}^{2}\right)\end{array}$ & $\begin{array}{c}10 \mathrm{~m} \\
\text { speed } \\
(\mathrm{m} / \mathrm{s})\end{array}$ & $\begin{array}{c}30 \mathrm{~m} \text { Wind } \\
\text { power density } \\
\left(\mathrm{W} / \mathrm{m}^{2}\right)\end{array}$ & $\begin{array}{c}30 \mathrm{~m} \\
\text { speed } \\
(\mathrm{m} / \mathrm{s})\end{array}$ & $\begin{array}{c}50 \mathrm{~m} \text { Wind } \\
\text { power density } \\
\left(\mathrm{W} / \mathrm{m}^{2}\right)\end{array}$ & $\begin{array}{c}50 \mathrm{~m} \\
\text { speed } \\
(\mathrm{m} / \mathrm{s})\end{array}$ \\
\hline 1 & $\leq 100$ & $\leq 4.4$ & $\leq 160$ & $\leq 5.1$ & $\leq 200$ & $\leq 5.6$ \\
2 & $\leq 150$ & $\leq 5.1$ & $\leq 240$ & $\leq 5.9$ & $\leq 300$ & $\leq 6.4$ \\
3 & $\leq 200$ & $\leq 5.6$ & $\leq 320$ & $\leq 6.5$ & $\leq 400$ & $\leq 7.0$ \\
4 & $\leq 250$ & $\leq 6.0$ & $\leq 400$ & $\leq 7.0$ & $\leq 500$ & $\leq 7.5$ \\
5 & $\leq 300$ & $\leq 6.4$ & $\leq 480$ & $\leq 7.4$ & $\leq 600$ & $\leq 8.0$ \\
6 & $\leq 400$ & $\leq 7.0$ & $\leq 640$ & $\leq 8.2$ & $\leq 800$ & $\leq 8.8$ \\
7 & $\leq 1000$ & $\leq 9.4$ & $\leq 1600$ & $\leq 11.0$ & $\leq 2000$ & $\leq 11.9$ \\
\hline
\end{tabular}

\subsection{Statistical Analysis of Wind Speed Distribution}

This section comprises of five main subsections which is adjustment of anemometers height, statistical analysis of Weibull and Rayleigh distribution, prediction performance of Weibull and Rayleigh distribution, wind power density and wind energy density and correlation and multiple regression analysis. 


\subsubsection{Adjustment of Anemometers Height}

Generally, the elevation of anemometer is different for each selected location. Thus, the wind speeds quoted must be adjusted to the same level of height. The standard height according to the World Meteorological Organization was $10 \mathrm{~m}$ above the ground level (World Meteorological Organisation 1964). The formula is given in as:

$$
\frac{V_{1}}{V_{2}}=\left(\frac{H_{1}}{H_{2}}\right)^{\alpha}
$$

Where:

$V_{1}=$ wind speed at height $H_{1}$ of $10 \mathrm{~m}$ above the ground level

$V_{2}=$ wind speed at height $H_{2}$ above the ground level

$\alpha=$ power law exponent, which depends on the surface roughness and atmospheric stability.

It is chosen by the method of (Justus and Mikhail, 1976) in accordance with the anemometer height and mean wind speed. The value of $\alpha$ is varied from 0.25 to 0.30 (Exell and Fook, 1986). Besides, the common heights of wind turbines from $30 \mathrm{~m}$ to $50 \mathrm{~m}$ above the ground level has been analysed in this study (Ahmed Shata and Hanitsch, 2006, Li and Li, 2005).

\subsubsection{Statistical Analysis of Weibull and Rayleigh Distribution}

In a statistical analysis, there are many methods that can be used to analyze the data. Commonly, Weibull and Raleigh distribution model has been used to analyze the 
data due to the versatility and simplicity. . The Weibull law is the most frequently used model to describe of wind speed. Weibull distribution can be characterized the probability density function, PDF and cumulative density function, CDF. The probability density function is given by:

$$
f(V)=\frac{k}{c}\left(\frac{V}{c}\right)^{k-1} e^{-\left(\frac{V}{c}\right)^{k}}
$$

Where:

$k=$ dimensionless Weibull shape parameter

$c=$ scale parameter measured in meter per second unit.

The $k$ values range from 1.5 to 3.0 for most wind conditions (Kavak Akpinar and Akpinar, 2005). A higher value of $k$ such as 2.5 or 4 indicates that the variation of mean wind speed is small. A lower value of $k$ such as 1.5 or 3 indicates a greater deviation away from mean wind speed (Bhattacharya and Bhattacharjee, 2009) A lower shape factor will normally lead to a higher energy production for a given average wind speed (van Alphen et al., 2007).

The cumulative distribution function, CDF is given by (Ramachandra et al., 1997, Elamouri and Ben Amar, 2008, Kavak Akpinar and Akpinar, 2005, GenÇ, 2010, Mayhoub and Azzam, 1997, Ahmed Shata and Hanitsch, 2006, Celik, 2007, Ozerdem et al., 2006, Vogiatzis et al., 2004, Weisser, 2003, Johnson, 1985, Manwell et al., 2002, Li and Li, 2005, Karsli and Gecit, 2003, Darwish and Sayigh, 1988, Rehman and Ahmad, 2004): 


$$
F(V)=1-\exp \left(-\left(\frac{V}{c}\right)^{k}\right)
$$

There are many methods which can be used to determine the shape parameter, $k$ and scale parameter, $c$. The common methods for determine both parameters were graphical method, standard deviation method, moment method and maximum likelihood method as well as energy pattern factor method (Manwell et al., 2002). (Ahmed Shata and Hanitsch, 2006) have explained that the root mean square error (RMSE) for maximum likelihood method was always lowers than others methods. Meanwhile, the graphical method was inaccurate and the results were affected by the bin size in the cumulative distribution format. The maximum likelihood method was used for the wind speed data analysis. This method was used by (Stevens and Smulders, 1979) in their study for the estimation of parameters of Weibull wind speed distribution for the wind energy utilization purpose.

The shape parameter $k$ and the scale parameter $c$ of Weibull distribution with maximum likelihood method is given by (Merzouk, 2000, Celik, 2003, Lun and Lam, 2000, Akdag and Dinler, 2009, Eskin et al., 2008, Ramírez and Carta, 2006, Bagiorgas et al., 2007, Rehman and Ahmad, 2004, Ahmed Shata and Hanitsch, 2006) :

$$
k=\left(\frac{\sum_{i=1}^{n} V_{i}{ }^{k} \ln \left(V_{i}\right)}{\sum_{i=1}^{n} V_{i}^{k}}-\frac{\sum_{i=1}^{n} \ln \left(V_{i}\right)}{n}\right)^{-1}
$$


and

$$
c=\left(\frac{1}{n} \sum_{i=1}^{n} V_{i}^{k}\right)^{1 / k}
$$

Where $V_{i}(\mathrm{i}=1,2,3, ., \mathrm{n})$ are the observed mean monthly wind speeds and $n$ is the number of nonzero wind speed data points.

The shape and scale parameters are closely related to the mean value of the wind speed, $v_{m}$ as (Ulgen and Hepbasli, 2002):

$$
v_{m}=c \Gamma\left(1+\frac{1}{k}\right)
$$

Where $\Gamma$ denotes the Gamma function. The gamma function has the properties of :

$$
\Gamma(\mathrm{x})=\int_{0}^{\infty} \xi^{\mathrm{x}-1} \exp (-\xi) \mathrm{d} \xi
$$

and

$$
\Gamma(1+\mathrm{x})=\mathrm{x} \Gamma(\mathrm{x})
$$

Furthermore, the standard deviation is given as (Ramachandra et al., 1997):

$$
\sigma=c \sqrt{\left[\Gamma\left(\frac{k+2}{k}\right)-\Gamma^{2}\left(\frac{k+1}{k}\right)\right]}
$$


The most probable wind speed and the wind speed carrying maximum energy have been calculated once the value of shape and scale factor is given. The most probable wind speed indicates the most frequent wind speed for a given wind probability distribution and is expressed by (Chang et al., 2003):

$$
V_{M P}=c\left(\frac{k-1}{k}\right)^{1 / k}
$$

The wind speed carrying maximum energy represents the wind speed that carries the maximum amount of wind energy and is expressed as follows (Jamil et al., 1995):

$$
V_{M A X E}=c\left(\frac{k+2}{k}\right)^{1 / k}
$$

The Rayleigh distribution is a subset of the Weibull distribution and has one parameter. It is simply to execute and it given as (Jangamshetti and Rau, 1999):

$$
f(v)=\frac{\pi V}{2 v_{m}^{2}} e^{\left[-\frac{\pi}{4}\left(\frac{V}{v_{m}}\right)^{2}\right]}
$$

The Equation 2.27 can be simplified as:

$$
f(v)=\frac{V}{c^{2}} e^{\left(-\frac{V}{2 c^{2}}\right)}
$$

